This is an Accepted Manuscript of an article published by Taylor \& Francis in [JOURNAL TITLE] on [date of publication], available online: http://www.tandfonline.com/10.1080/00074918.2014.980380 http:// authorservices.taylorandfrancis.com/sharing-your-work/ (Publisher journal website 5/9/2017)

\title{
The Role of Health Insurance Membership in Health Service Utilization in Indonesia
}

\author{
Yogi Vidyattama \\ University of Canberra \\ Riyana Miranti \\ University of Canberra \\ Budy P. Resosudarmo \\ Australian National University
}

\begin{abstract}
In 2014 Indonesia implemented a new subsidised nationwide universal coverage health insurance program where poor Indonesians do not pay to become members of this program, while others pay a relatively low fee. This program has caused national debate as to how effective is the ownership of health insurance in increasing the utilisation of health services, particularly among the poor, given the existing quantity and quality of health services. Utilising membership data available in the 2007 Susenas-Riskesdas dataset for various health insurance programs, this paper aims to research the impact of having health insurances on the utilisation of health services, by controlling the levels of quality and quantity of health services in the area. This paper argues that having health insurance would increase health service utilisation by approximately 8 percentage points when people feel sick or by approximately 5 percentage points if it included those who do not feel sick.
\end{abstract}

Keywords: Health Insurance; Development Studies; Policy Impact

JEL codes: I13; I15; I38; 015

(Published in the Bulletin of Indonesian Economic Studies, 2014, vol. 10, no. 3, pp.

319-333) 


\section{Introduction}

Since the early 2000 s, the Indonesian government has been interested in rolling out a subsidised nationwide universal coverage health insurance program, not least because of the still relatively high out of pocket expenditure as a percentage of private expenditure on health and the issue of inequity of health care utilisation, particularly for the poor, in the 2000s. Health insurance program is expected to reduce this relatively high out of pocket expenditure. (Aji et al., 2013). ${ }^{1}$

Out of pocket health expenditure as a proportion of private health expenditure in Indonesia was approximately 80 per cent between 2005 and 2008, then dropped to approximately 77 per cent between 2009 and 2011. In comparison, percentages for Malaysia and Thailand were approximately lower at 76 and 66 per cent, respectively, for 2005 to 2008, and 77 (relatively stagnant for Malaysia) and 57 for 2009 to $2011 .{ }^{2}$

Low health care utilisation, particularly among the poor, was also an issue in Indonesia particularly in the early 2000s. It was reported that in 2001 the ratio of consultation rates for doctors among people in the poorest and the richest quintiles was 0.8 (OECD/WHO, 2012). It was expected that the ratio should be closer to 1 .

On the other hand, several challenges in implementing a subsidised nationwide universal coverage health insurance program have also been so far identified, in particular, the supply side of providing health services. There have been some doubts that Indonesia will be able to significantly increase quantity and quality of health services, if it does decide to implement a subsidised universal health insurance.

\footnotetext{
1 Please note that the relationship between out of pocket expenditure and health insurance is a complex one. We do not discuss this relationship since it is beyond the scope of this paper.

2 Authors' calculation based on World Bank - Word Development Indicators (2013)
} 
First, disparity among levels of development in Indonesia remains high (Vidyattama, 2013). Particularly in less developed areas with challenging geographical conditions, there are concerns about whether there are enough access to health services and whether there is enough information targeted to the poor so they can understand the benefits of a subsidised universal coverage health insurance.

Second, it has been argued that the provision of universal health insurance may potentially add more burdens to the capacity of the public health system which has been argued as already stretched even without the application of this universal scheme (World Bank, 2012).

Third, the supply of health providers, especially at public side, has also been affectd by various economic downturns. The 1998 economic crisis had reduced the funding availability allocated to maintain network of health centres (hospital, puskesmas and posyandus) (Hotchkiss and Jacobalis 1999). In addition, the decentralisation has placed the administration of the formerly centralised network to the local government. Although some of the health centres have benefited from funding allocated by its local government, many have faced issues regarding to the transparency in the local government management and lack of fund available in certain district governments (Kristiansen and Santoso, 2006). This affected the supply provision of public health providers or facilities.

It is, hence, important to understand and anticipate the potential increase of demand toward the health services when universal subsidised universal health insurance is implemented. This paper provides such attempt to understand this issue.

In 2014, Indonesia implemented the subsidised nationwide universal coverage health insurance program: poor Indonesians do not pay to become members of this national health insurance program, while others pay a relatively low fee. As in all developing countries, this program has caused national debate as to how effective it 
is in increasing the utilisation of health services, particularly among the poor, given the existing quantity and quality of public health services.

Utilising membership data available in Indonesia for various health insurance programs; i.e. private/non-subsidised, partially subsidised and fully subsidised health insurance programs, this paper aims to research the role of health insurance membership in the decision to seek treatment at a health facility when one feels sick, controlling, among other factors, their accessibility and the levels of quality and quantity of health services in their area. This paper is also an attempt to estimate the impact of health insurance ownership on the utilisation of health services taking account their quantity and quality, regardless one feels sick or not; i.e. taking into account those utilising the services for preventive cares. Other individual demographic, socio-economic and geographical location characteristics affecting the effectiveness of health insurance membership in determining the decision to access health services will be observed as well. ${ }^{3}$

There have been many studies being done on the implementation of health insurance in various countries. For example, in China, it has increased hospital outpatient and inpatient utilisation (Wagstaff and Pradhan, 2005, Wagstaff et al., 2009). Similar result was also found in Senegal (Jütting, 2003). In Vietnam, among the poor in remote areas, it has not (Wagstaff, 2007; Ekman et al., 2008). Studies conducted among low-income countries also found that the impact of this policy is not significant for certain groups in society (Ekman, 2004; McIntyre, 2007). Hence, there has been serious debate regarding the effectiveness of such a policy. ${ }^{4}$ So far, studies on this subject in Indonesia have been relatively limited. Pradhan et al. (2007) assessed the effectiveness of the implementation of the social safety net health card program; providing free access to government health services for the

\footnotetext{
3 i.e. this paper observes the demand-side of health services with supply-side controls in place. True that there is also a supply-side issue, one example of which is low spending in terms of both public and private expenditure in providing health related facilities, but this is beyond the scope of this paper.
} 
poor, as a response to the Asian economic crisis in 1997/98. Hidayat et al (2004) and Hidayat and Pokhrel (2009) analysed the impact of mandatory health insurance for civil servant (Askes) and government-provided insurance scheme through PT. Jamsostek on out-patient visits at public and private health facilities.

This paper differs from those of Pradhan et al. (2007), Hidayat et al (2004) and Hidayat and Pokhrel (2009) in several ways. First, this paper investigates the impact of membership with regard to different health insurance schemes, whereas Pradhan et al. (2007) only examined the fully subsidised health insurance scheme for the poor and Hidayat et al. (2004) as well as Hidayat and Pokhrel (2009) only on Askes and PT. Jamsostek cases. Although this paper did not focus to measure the performance of each scheme, this paper attempts to observe possible variations in impact of membership of these various health insurance schemes.

Second, this paper will use the Riskedas (Riset Kesehatan Dasar or Basic Health Research) database 2007 combined with Susenas (Survei Sosial Ekonomi Nasional or National Socio Economic Survey) 2007. Riskesdas database covers the whole nation. Note that Hidayat et al (2004) and Hidayat and Pokhrel (2009) utilised the Indonesian Family Life Survey (IFLS) database, which does not cover the whole nation. Furthermore, Riskesdas database provides more reliable information on types of disease affecting household members and health service utilisation and includes other variables that are not captured in Susenas, which is the main data set utilised by Pradhan et al. (2007), but may be important when deciding whether to access the health services, including the travel time to the nearest health service provider and the distance to the provincial capital city.

Third, this paper's period of observation differs from those of Pradhan et al. (2007), Hidayat et al (2004) and Hidayat and Pokhrel (2009). Their period of observation is during the financial crisis of $1997 / 98$, as opposed to 2007 in this paper, which can be considered to be a normal year. 
There are, however, shortcomings of this paper. Among other is the fact that this paper is unable to distinguish between the role of health insurance membership in the decision to seek treatment, when one feels sick, at a public health facility and that at a private health facility. This paper also does not discuss the impact of health insurance membership on out of pocket health expenditure. This paper will take into account these shortcomings when developing conclusions at the end of this paper.

The outline of this paper is follows. After the introduction, this paper briefly describes the development of health insurance in Indonesia, followed by some literature reviews on modelling health service utilisation. Then there is a section on model specification and data sources, followed by estimation results and a conclusion.

\section{Health insurance provision in Indonesia}

Health insurance in Indonesia has a long history, reaching back into the colonial period when insurance companies provided insurance policies to middle income earners and organisations such as labour unions established mutual health insurance plans for members. Such forms of health insurance were continued after independence in 1945 (Soedjono 1956). The first major government attempt to introduce health insurance for public servants took the form of Asuransi Kesehatan (Askes) in 1968, as Table 1 shows. ${ }^{5}$

In 1969, the Health Fund (Dana Sehat) program, operating under a micro-finance scheme was introduced by several community organisations and was supported by the government to provide a kind of health insurance for its members. It replaced the unsuccessful Sickness Fund (Dana Sakit) program. Despite the government's

\footnotetext{
${ }^{5}$ Prior to the 1968, there were already private health fund schemes, mostly by labour unions or social organisations such as Muhammadiyah or other religious groups, and generally served middle-income earners. Nevertheless, they were not public schemes nor general schemes and only had limited coverage.
} 
support in promoting the Health Fund program, this program was not able to take off as a program for the majority of Indonesia (Nugroho and Elliott, 1977). High dropout rates, low quality of benefits, limited coverage, and issues of access for the poor were among the reasons why this program has not been successful (Thabrany et al., 2003).

In 1992, a new community based health insurance program, JPKM (Jaringan Pemeliharaan Kesehatan Masyarakat), was launched in parallel with the implementation of the Health Fund (Soors et al., 2010). This was the Indonesian version of the Managed Care program inspired by the United States Health Maintenance Organisation Models (HMO), which combined a commercial based health insurance model with social aims to reach the poor population. Nevertheless, in practice, due to the underfunding of the program and the poor quality of the benefits, the coverage of the JPKM program was very low with fewer than 500 thousand people registered as members so this program was also considered to be unsuccessful and was put on hold for further expansion (Scheil-Adlung, 2004). At the same time (since 1992), Jamsostek (Jaminan Sosial Tenaga Kerja) was introduced to provide health insurance for private formal employees and employers. ${ }^{6}$

In 1994, the Ministry of Health introduced the first scale of Health Card program covering public health centres (Puskesmas) which was targeted to the poor households (Johar, 2009; 2010). Nevertheless, in practice, the cards were poorly distributed as there were no incentives and proper guidelines for Puskesmas to distribute the cards to the poor.

(Table 1 is here)

In 1998, as an effort to softening the impact of the 1997/98 Asian Financial Crisis among the poor, a major Social Safety Net program (SSN or Jaringan Pengaman Sosial) was implemented. Part of this program is the provision of an SSN large scale

\footnotetext{
${ }^{6}$ Please note that there is also Asabri or health insurance targeted to police or military members.
} 
health card (this was the second health card program) for the poor to allow them to receive free health treatment from government health centres Initially, the program was implemented using the JPKM-HMO model, with hundreds of the JPKM were established at the provincial/district levels. Nevertheless, most of the JPKM failed to perform so that the $\mathrm{MOH}$ took over the management of the program and distributed the fund directly to Provincial or District Health Offices instead.

Pradhan et al. (2007), from their impact evaluation research, found that approximately 34 per cent of households in the lowest quintile owned the health cards (if we include the second lowest quintile, card ownership amounted to 59 per cent) and the use of modern health care among the health cardholders increased. However, there were also challenges in terms of the implementation of the SSN program including the mistargeting issue as leakage to wealthier households was substantial. Wealthier households in the quintiles 4 and 5 still held about 20.4 per cent of the health cards (Pradhan et al., 2007). Further, the transportation issue and its related cost also hindered participation the program by the poor.

In 2004, the health card system was replaced by a health insurance program for the poor, Askeskin (Asuransi Kesehatan Masyarakat Miskin). The main objective of this scheme was to expand the social security program coverage to the informal sector. Sparrow et al. (2013) have argued that Askeskin has also been considered as successful in targeting the poor and increased the utilisation of outpatient services by the poor. Nevertheless, there is evidence for a slight increase in out-of-pocket spending in urban areas which is probably due to an increase in relatively more expensive hospital care that has not been fully covered by Askeskin (Sparrow et al., 2013).

Askeskin was then expanded into Jamkesmas (Jaminan Kesehatan Masyarakat) in 2008 to also cover (some of) the near poor population. ${ }^{7}$ The program was fully

\footnotetext{
${ }^{7}$ It is argued some of the near poor people were covered for the following reasons. First, targeting the near poor is difficult; second given that a large number of people are living just above the poverty
} 
financed by the Central Government and administered by the Ministry of Health with both public and private health providers involved. Despite its improvement in terms of coverage of the near poor population, for example, Harimurti et al. (2014) has argued that only approximately 47 per cent of the poor and near-poor households was covered by this program. Although there is an increase in utilisation rates, particularly for outpatient services, there have also been challenges. These include evidence of substantial mistargeting and leakages to the non-poor (20 per cent of Jamkesmas beneficiaries in 2010 were in the top 3 deciles), low levels of socialisation and awareness of benefits, inconsistencies across regions in terms of applying targeting criteria and providing basic benefit package, the relatively low levels of financial protection and poor accountability (Harimurti et al. 2014).

In addition to Jamkesmas, in several regions, regional governments also established a regional health insurance program called Jamkesda. Jamkesda is mostly designed as an extension of Jamkesmas, with the objective of covering an additional population of near poor, on top of those covered by Jamkesmas. ${ }^{8}$

It is important to note that by the 2000s various private health insurance programs had also been established in Indonesia. Major Indonesian banks such as BNI Bank, Mandiri Bank and BCA Bank offered private health insurance programs to their clients. Private health insurance can also be obtained from several private Indonesian insurance companies, such as PT Sinarmas, PT Adisarana Wanartha and PT Tugu Mandiri. Multinational insurance companies too, such as Prudential, Allianz and Commonwealth Life, have entered the Indonesian health insurance market.

Based on the Ministry of Health data (2013), by December 2012, more than 163 million people or 68.8 per cent of total population were one way or another covered

\footnotetext{
line, a slight change in the definition of "near poor" means a lot of people fall either in or out of the near poor group. To give an idea of the numbers of people missing out, an assessment by the World Bank (2011) claimed that approximately 52 per cent of the poorest 30 per cent of the population were still without health insurance in 2010.

${ }^{8}$ In the next sections of this paper, these various health care programs will be included as health insurance; i.e. the definition of health insurance in the next sections of this paper will include health care, since health care is considered to be fully subsidised health insurance.
} 
by health insurance. Jamkesmas, covering more than 76 million people in 2010, is the largest health insurance provider. Nevertheless, approximately 30 per cent of Indonesians, mostly comprising the near poor and the poor, are still not covered by any kind of medical insurance.

Starting on 1 January 2014, the Indonesian Government launched the first stage of the application of the new 'Universal National Health Insurance' scheme organised by a newly established organisation, the Social Security Management Agency (Badan Penyelenggara Jaminan Sosial or BPJS). This new scheme will integrate Jamkesmas with all other health insurance programs including Askes, Jamsostek and some of the Jamkesda schemes. The launch of this program was based on two pieces of legislation. Firstly is the law of the National Social Protection System (Sistem Jaminan Sosial Nasional or SJSN), Law No. 40/2004, and secondly is the Legislation on the Social Security Management Agency (Badan Penyelenggara Jaminan Sosial or BPJS), Law No. 24/2011.

The BPJS has set the first stage of the target to insure at least 121.6 million people by end of 2014, while the final target of the scheme is to provide insurance service to the whole population (at around 240 millions) by 2019. The aim is to provide a comprehensive package, which includes not only curative services but also preventive and rehabilitative services and to cover all types of natural sickness.

The calculation of the resource is complex and depends on the employment status of the recipients. For example, the government will provide a monthly subsidy for people categorised as poor. However, the employer and employee should share 5-6 per cent wages to pay the insurance premium, while those who work in the informal sector should contribute self-funded contributions of 5-6 per cent of their monthly income (Simmonds and Hort, 2013).

\section{Conceptual Framework}

This paper, in general, aims to develop a reduced demand function of health services; i.e. a demand function that takes into account various conditions of the 
supply side, with particular attention to membership and the types of health insurance held. The most widely cited model on this issue is the Behavioural Model (BM) developed in 1968 by Ronald M. Andersen, US medical sociologist (Andersen, 1968). In the latest development of this BM, the three groups of factors that should be in the model are the following (Babitsch et al. 2012). Firstly is a group consisting of predisposing factors, which include individual characteristics such as age, sex, ethnicity and family type, demographic and social composition of communities and cultural norms. Secondly is a group consisting of enabling factors. These include factors such as income and wealth of an individual as well as factors representing the supply side of the health services such as the availability of health service facilities and personnel, travel time and means of transportation. Health insurance is also included as an enabling factor (Babitsch et al. 2012). Thirdly is a group consisting of need factors which are perceived need for health services, individuals' perception of their need to utilise health care, and evaluated need i.e. professional assessment of patients' health status and the need for care.

In implementing this model, other researchers also add other determinants or differently modify the model. One of the common additional determinants is spatial region/location of residence. Pradhan et al. (2007) argued the importance of this determinant due to, in their case, systematic differences between regions in the allocation of health insurance coverage (health card) and health care funding. The importance of spatial location is also the focus of Erlyana, Damrongplasit and Melnick's study on utilisation of health services (Erlyana et al., 2011).

A modified version of the BM, for example, was conducted by Lopez-Cevallos and Chi (2010) for Ecuador. In their work, they developed need factors based on individual responses when having health problems during a certain period and on how many health problems were mentioned in the past. They also divide utilisation of health care services into preventive care (for example, if an individual has visited a physician for a preventive appointment in the last 30 days) or curative care (for example, whether or not an individual has visited a physician for a curative appointment in the last 30 days or has been hospitalised in the last 12 months. 
Another modification is to extend the implementation of the model for other analysis. For example Jütting (2003) who analyses the impact of a community-based health insurance scheme for the poor in rural Senegal, not only uses a similar approach as the BM for health care use, but also for health care expenditure. A similar extension was conducted by Sparrow et al. (2013) for an Indonesian case. They observed the determinants of utilisation of outpatient facilities (number of visits in last month) at public and private health care providers, out of pocket health spending, and incidence of catastrophic spending defined as health spending that exceeds 15 per cent of total household spending.

A different approach was taken by Ensor and Cooper (2004). They indirectly examine the determinants of the utilisation of health care through identifying its barriers from the supply and demand sides of health services. The supply side includes input prices covering the cost of staff, capital equipments and buildings, knowledge of treatment technology and management efficiency. The demand side includes cover prices (which are official and unofficial charges, travel costs and opportunity costs of lost work), household characteristics (including incomes and level of education), cultural characteristics, and knowledge of health care available.

In estimating these health service utilisation models, the most common issues mentioned are self-selection and endogeneity issues. The self-selection issue is due to the fact that, most of the time, non-sick people are not included in the regression sample (Jutting, 2003). The endogeneity issue is due to a possible reverse causality direction between insurance holders and demand for health care (Sparrow et al., 2013). Also people who join a health insurance program might have unobservable characteristics, which will make them more likely to join the program and might influence the decision to use a health care service (Walker, 1999).

\section{Model Specification and Data Sources}


To research the role of health insurance membership in the decision to seek treatment at a health facility when one feels sick, this paper utilises a version of the BM specified in the following conditional probit model:

$$
\operatorname{Pr}\left(Y_{i}=1 \mid X_{i}=1\right)=\alpha+\beta_{H} H_{i}+\mathbf{P}_{\boldsymbol{i}} \boldsymbol{\beta}_{\boldsymbol{p}}+\mathbf{E}_{\boldsymbol{i}} \boldsymbol{\beta}_{\boldsymbol{e}}+e_{i}
$$

where $\operatorname{Pr}\left(Y_{i}=1 \mid X_{i}=1\right)$ is whether or not a person utilised a formal health service $\left(\operatorname{Pr}\left(Y_{i}=1\right)\right)$, given he/she felt sick $\left(X_{i}=1\right)$ last month. Being an outpatient (or "berobat jalan" in Indonesian) in the previous month is the binomial variable representing utilising formal health services. For estimating the equation (1), this paper limits its sample to include only those reporting feel sick last month.

$H_{i}$ is whether or not an individual $i$ owns any health insurance or is covered by a health care program. This is the main variable of interest in this paper. It is a binomial variable. $\mathbf{P}_{\boldsymbol{i}}$ is a vector of predisposing variables covering factors such as age, sex, marital status, number of family members and education level. $\mathbf{E}_{\boldsymbol{i}}$ is a vector of enabling variables which include factors such as employment status, household food expenditure as a proxy of income and variables representing physical access and the condition of the supply sides of health services. Several geographical variables are included as an effort to control the quality of the supply side of health services in the area, which are factors such as the time needed to get to the nearest medical centre, Gross Regional Product (GRP) per capita in the resident's district, local government health budget per capita, distance from the district to provincial capital cities as well as dummies for the island of the resident.

This paper is also interested to observe the role of health insurance membership in the decision to utilise health services regardless one feels sick or not; i.e. to include utilising health services for preventive activities such as vaccination. If information on whether or not a person utilised a formal health service last month, even he/she did not feel sick last month, is available in the 2007 Susenas-Riskesdas dataset, the model to be estimated using the whole sample is: 


$$
\operatorname{Pr}\left(Y_{i}=1\right)=\alpha+\beta_{H} H_{i}+\mathbf{P}_{\boldsymbol{i}} \boldsymbol{\beta}_{\boldsymbol{p}}+\mathbf{E}_{\boldsymbol{i}} \boldsymbol{\beta}_{\boldsymbol{e}}+e_{i}
$$

Susenas and Riskesdas surveys, however, only asked whether or not a person utilised a formal health service last month, if the person reported that he/she felt sick last month. To overcome this missing information, the following two approaches are taken. First, correcting the selection bias issue in estimating equation (1) using only those reporting feel sick last month with the Heckman correction procedure to the whole sample (Heckman, 1979). This paper uses the existence of a widespread outbreak of an infectious disease in a village as the main instrument to predict whether or not someone in the village will be reporting feel sick last month. ${ }^{9}$ If the instrument is strong, $\beta_{H}$ should be a good enough parameter in representing the impact of health insurance membership in the decision to utilise health services regardless one feels sick or not. Second, this paper re-estimates equation (1) the whole sample; i.e. including those not reporting feel sick last month. This procedure is equal to estimating the following joint probit model using the whole sample:

$$
\operatorname{Pr}\left(Y_{i}=1 \cap X_{i}=1\right)=\alpha+\beta_{H} H_{i}+\mathbf{P}_{\boldsymbol{i}} \boldsymbol{\beta}_{\boldsymbol{p}}+\mathbf{E}_{\boldsymbol{i}} \boldsymbol{\beta}_{\boldsymbol{e}}+e_{i}
$$

Assuming that $\operatorname{Pr}\left(X_{i}=1 \mid Y_{i}=1\right) \approx 1$ (i.e. given the person is utilizing health services last month, the person is most likely reporting feel sick last month), implies $\operatorname{Pr}\left(Y_{i}=1 \cap X_{i}=1\right) \approx \operatorname{Pr}\left(Y_{i}=1\right) .{ }^{10}$ This is not a bad assumption since visiting a health centre for preventive care is not yet that common in Indonesia.

The main dataset for this paper came from the Indonesian Socio-Economic Survey (Susenas), an annual national survey conducted since 1963 that includes data on both the household (such as size of household, household expenditure and type of housing and amenities) and the individual (such as education level, employment status, sex and age). This paper utilises data from the Core Susenas module of 2007,

\footnotetext{
9 The empirical results of this paper show that a widespread outbreak of an infectious disease is a valid instrument as its correlation with the error term of the main equation estimated is relatively insignificant (i.e. less than 1 percent).

10 Note that $\operatorname{Pr}\left(Y_{i}=1 \cap X_{i}=1\right)=\operatorname{Pr}\left(X_{i}=1 \mid Y_{i}=1\right) \cdot \operatorname{Pr}\left(Y_{i}=1\right)$
} 
since its 280 thousand sample households are also the sample for the 2007 basic health survey (Riskesdas) based on interviews with the heads of households (Ministry of Health, 2008). Therefore, the two databases can be merged and provide a better picture of the condition of Indonesian households and individuals especially in relation to health. At the individual level, the database for this paper contains, in total, 856,592 observations. Considering the way the samples for Susenas and Riskesdas were constructed and the size of these samples, it can be argued that the dataset utilised in this paper is representative of the country's general population.

The ability to merge the 2007 Susenas and Riskesdas datasets is the main reason not to utilise the latest available Susenas dataset, which is from the 2012 survey. The combination of the 2007 Susenas and Riskesdas data provides more information on individual health status and they are more reliable than the 2012 single survey. ${ }^{11}$

The other reason is this paper would have to have a smaller data set to make proper use of data from the 2012 Susenas survey. In 2012, Susenas surveys were carried out on quarterly basis and so much of the information is not that comparable due to some seasonal changes with each quarter. This paper would have to limit its data to information from one of these quarterly surveys, which only contain approximately 270 thousand individuals. Please note, nevertheless, the result from 2012 Susenas dataset are not much different than those from the 2007 Susenas-Riskesdas dataset.

Among the many variables utilised from the 2007 Susenas-Riskesdas dataset, the main information of interest is on ownership of health insurance (including being covered by a health care program). The dataset provides information on ownership of or being covered by seven health insurance groups: (1) health insurance for civil servant (Askes), (2) social insurance for worker (Jamsostek), (3) private health insurance, (4) company's financial reimbursement, (5) health care for the poor, (6)

\footnotetext{
11 Please note, though information on self-reported being ill and different types of symptoms is also available in Susenas, this paper utilizes those available in Riskesdas. This paper believes the information in Riskesdas is a more reliable one. Nevertheless, this paper acknowledges the problems with self-reporting information.
} 
community health fund, and (7) JPKM and other regional insurance schemes. The Askes group also includes insurance for armed forces veterans and civil service retirees. The health care for the poor group includes several different schemes targeting people with lower income, such as Askeskin/Jamkesmas, JPKMM (Jaminan Pemeliharaan Kesehatan Masyarakat Miskin), Health Card (Kartu Sehat) and JPK Gakin (Jaminan Pemeliharaan Kesehatan Keluarga Miskin).

Furthermore the dataset also provides detail on eight types of illness. It is possible to choose from one or more of eight illnesses: fever, coughing, cold, asthma, diarrhoea, headache, toothache and other unspecified illnesses. As mentioned before, the proxy for utilisation of health service is being in outpatient care or not in in the past month. Having different types of health insurance programs and illnesses allows this paper to conduct a comprehensive investigation into the impact of different types of health insurance/care programs on health service utilisation when one faces different types of illness; the response regarding being an outpatient could be different depending on the type of illness and the type of health insurance programs that one has. Table 2 shows the percentage of health insurance ownership and outpatients by types of illness and regions in 2007.

(Table 2 is here)

The first row in Table 2, it can be seen that in 2007 approximately 14 per cent of individuals in Indonesia were outpatients in the previous month and it is also estimated that 27 per cent of Indonesians had some kind of health insurance. Nusa Tenggara reported the highest proportion of outpatients at 20 per cent and also the highest proportion covered by health insurance at 43 per cent.

The "Not ill" row shows those reporting not affected by any illness in the previous month, while the "Any illness" shows the situation of those reporting feel sick affected by any illness in the previous month. From this row, it can be seen that approximately 45 percent who reported sick in the previous month sought medical treatment and were treated as outpatients. Among those who reported sick only 
approximately 28 percent had any kind of health insurance. Rows below the "Any illness" show the situation of those reported sick in the previous month in each region. The last group of rows in this table shows the situation of those reporting sick affected by a certain type of illness. For example, approximately 26 percent of those who had a fever in the previous month received outpatient treatment.

\section{Results and Discussion}

\subsection{Regression Quality}

Table 3 shows the results from the main estimations conducted in this paper. Probit regression is the estimation technique utilised for all estimations. The technique uses the maximum likelihood to cumulative distribution function of normal distribution to estimate the coefficients in the regression. This is one of the most efficient unbiased regression techniques available.

The main concern with the results in Table 3 is whether or not there is an endogeneity bias in our estimation. There are two possible sources of this bias: (1) having health insurance is due to the fact that one expects to become ill (or reverse causality issue), and (2) omission of important variables determining health service utilisation which also have some correlation with health insurance ownership (i.e. omitted variable issue). Related to the first source, this paper argues that this is not the case. First, among those with health insurance, the proportions of those who are outpatients are relatively smaller than those who are not (see columns (3) and (4) in Table 2). ${ }^{12}$ The proportion of outpatients should be much larger if there were a potential endogeneity issue. The main reason for this is that, knowing that they are going to use health services, they become members of health insurance.

Second, the majority of those with health insurance have it by default (or mandatorily) due to being civil servants, poor or near poor; they do not have it by choice. Private health insurance is the only scheme where it can be suspected that

\footnotetext{
12 By substracting columns (3) with (4) in row "All person", it can be seen that the proportion of people with health insurance but not utilizing health services is approximately 21.8 percent of the population; much larger than 4.7 percent of the population having health insurances and utilising health services.
} 
those having it might do so due to expectation of being sick now or in the future. However, the proportion of those with private health insurance is relatively small. Related to second source of possible bias, this paper put as many as possible determinants in the regressions. It is important to note with that this strategy does not entirely solve the problems of unobserved heterogeneity. Having a panel data analysis is most likely a better approach to solve the problems of unobserved heterogeneity. However, the dataset utilised in this paper do not allow us to implement a panel data analysis. The models implemented in this paper include a relatively a lot of variables, they include education, household size, age, income, employment status and sector of employment. This should minimise the possibility of bias due to omission of important determinants. ${ }^{13}$ Hence, it is safe to argue that results in Table 3 are relatively unbiased.

To ensure the robustness of the results of this paper, an alternative method, namely the Average Treatment Effect to those who utilise the health service using different degree of matching (Rosenbaum and Rubin, 1983; Heckman et al 1997), is also applied. The results of this method confirm that results in Table 3 are relatively robust. ${ }^{14}$

Models (1a) and (1b) in Table 3 shows the determinants of health utilisation among those reporting feel sick last month. Models (1c) and (1d) shows the results of Heckman correction procedure aiming to estimate the determinants of health utilisation among all individuals; i.e. both reporting and not reporting feel sick last month. Models ( $3 a$ ) and (3b), by estimating the equation (3), also aim to estimate the determinants of health utilisation among all individuals.

Heckman (1979) argues that if having health insurance has a high correlation with being sick, Heckman correction's estimation procedure will produce relatively unbias estimation results. In this paper, however, the correlation coefficient between

\footnotetext{
${ }^{13}$ To further reduce this issue, one needs to utilize a longitudinal dataset. Unfortunately the Susenas-Riskesdas dataset is not.

${ }^{14}$ Results using the Average Treatment Effect are available from the authors upon reques.
} 
health insurance ownership and being sick is only 4.85 per cent. Furthermore, an application of Heckman correction's estimation procedure produces less efficient estimation results as indicated by much lower numbers of log likelihood compared to the pure probit model in models ( $3 a$ ) and (3b). Hence, it seems reasonable to believe that models ( $3 a$ ) and (3b) provide a more accurate estimation than models (1c) and (1d).

(Table 3 is here)

\subsection{The Impact of Health Insurance}

It is important to note that Table 3 presents the marginal effects calculated from the results of the probit regressions. It can be seen from models (1a), (1b), (3a) and (3b) that the impact of health insurance ownership on health service utilisation is positive and statistically significant. Model (1a) shows that ownership of any health insurance increases the probability of utilising health services by 7.5 percentage point when one feels sick. When observing the results for the whole sample, regardless one feel sick or not, ownership of any health insurance increases the probability of utilising health services by 4.8 percentage point (model (3a)).

Different health insurance programs, however, induce different impacts on the utilisation of health services (see models (1b) and (3b)). Among those feeling sick or for the whole population, private health insurance, health cost reimbursement by company and Jamsostek increase the utilisation of health services less than the others. This is logical since most members of private health insurance, health cost reimbursement by company and Jamsostek are, in general, are better off than civil servants, those informal sectors and the poor. This result highlights the importance of subsidised health insurance to enable people to seek health services when they 
feel sick or for preventive cares-so achieving the final goal of better health status for society as a whole. ${ }^{15}$

The result may not be able to confirm whether there is a concern regarding enrolment rate in Indonesia. In his assessment on the implementation of Universal Health Insurance in Asian countries, Wagstaff (2014) points out that the enrolment to this insurance among middle income household is often low as the benefit may not be felt as great. Most of the enrolment in the schemes that involve middle class in our study has been taken care by the employers or the institution that working with them. Nevertheless, the relatively high impact of the Askes and Jamsostek indicate that the middle income in Indonesia will be willing to utilise the health insurance. Wagstaff (2014) himself points out that the issue is less pronounced in Indonesia compared to the Philippines and Vietnam. One issue that Indonesia needs to face is ensuring that the reduction in out-of-pocket spending is significant but at least the provider payment from the insurance could be an incentive for the provider to improve its services (Perrot et al 2010).

\subsection{Other Determinants of Health Service Utilisation}

The impact of the predisposing factors on health service utilisation is arguably smaller than the enabling factor of the ownership of health insurance. The impact of age is small and single people are less likely to utilise health services or seek medical treatment compared to those who are married, widowed or divorced. ${ }^{16}$ One explanation could be that single people, who are mostly young, are more careless about seeking health treatment when they are sick, believing that they can recover by purchasing over the counter medicines. Among general population, females are less likely to seek medical treatment. When they feel sick, there is no significant difference between female and male. This could be the fact that Indonesian female

\footnotetext{
15 Important to note is that in 2007, the year of this paper's database, the owners of health insurance for civil servant, health care for the poor and community health fund can, most of cases, only use these program when visiting public health providers. The results of this paper could be different if they are allowed to utilize these programs to seek private health services, due to the fact that, in Indonesia, private health providers typically provide better services and are having superior facilities than those of public health providers.

${ }^{16}$ Among those feeling sick there is not much difference between single people and divorced.
} 
feel a higher opportunity cost than males do or that Indonesian females are more careful in managing their money. And so they only seek health treatment when they are really sick, otherwise using medicines available over the counter.

In estimating the impact of education, this paper uses those who have no school education as a comparison base. The estimation shows all education levels have a negative impact on health service utilisation. Furthermore, the higher a person's education is, the less likely they are to use health services when they are sick. One of the explanations for this result is that the observations who have no school education are dominated by children especially those aged five years old and below whose, in Indonesian culture, would have the priority to be taken to seek medical treatment when they are sick due to their fragility. Another explanation is because their opportunity cost of using health services rises in proportion to their education level, and it could also mean they are more confident to treat their illness themselves by buying over the counter medicines. These results are also in line with the negative impacts of all employment status (with not working as a comparison base). This may indicate that the opportunity cost of not going to work because of sickness and using the health services for consultation instead is high.

Household income, which is proxied by food expenditure, is significant in determining the utilisation of health services. The richer the person, the more the person utilises health services when sick. This an indication that in general there still could be the existence of budget constraints in utilizing health services, even among the poor. Health services might be free for them, but they still have to cover the travel cost to reach health services from their homes. That this could be an issue is borne out by the fact that the farther the person is from a health centre, the less likely they are to utilise the health centre when sick.

The quality of health services seems to matter as well. It can be seen that the farther the person is from a provincial capital (i.e. the person has to go to local health centres which most likely provide lower quality than those in the provincial capital), the less likely they are to utilise health services when sick. Living outside the 
Java-Bali, except in Nusa Tenggara, also reduces the probability of utilising the health services. This may be because of the availability and quality of health services in Java-Bali is better than outside Java but it may also affected by the availability of better information in Java-Bali about the importance of seeking accredited medical treatment. However, it is puzzling that those living in Nusa Tenggara have a tendency to utilise health services more often than those in Java-Bali when they are sick. The answer could be that the types of illnesses that they typically had in 2007 might more pressingly have required them to seek professional medical treatment (Pakasi et al 2009; Soenarto et al 2009).

\subsection{Users of Health Insurance}

This paper seeks to understand who uses of health insurance by adding interaction variables between having health insurance and various individual and location characteristics and observing the coefficients of the variable. Table 4 shows the marginal effects of the additional variables. This is because, except for health insurance, the marginal effects for other variables are hardly affected by the inclusion of these additional variables.

First this paper focuses on understanding people in regions in which people generally use health services when they are sick and have health insurance. Note by the absence of the Java-Bali dummy variable the marginal effects of different regions have to be seen relative to the condition in Java-Bali. The result indicates that having health insurance in Sumatra, Kalimantan and Sulawesi tends to encourage the owners to use health services more than in Java-Bali; i.e. health insurance companies/schemes tend to "better help" people on those island to access health services than those in Java-Bali. This is not the case in Nusa Tenggara; i.e. the effectiveness of health insurance in increasing health in those regions is not better than that in Java-Bali. In Maluku-Papua, the results are interesting. Among people who feel sick, people in Maluku-Papua who have health insurance tend to utilise health services when they feel sick compared to those in Java-Bali. However, this is not the case when those who do not feel sick included; i.e. having health insurance does not encourage people in Maluku-Papua to do any preventive care. 
Table 4 shows an insignificant positive coefficient of interaction between having health insurance and the time needed to reach the nearest health centre. It means that having health insurance encourages the use of health service the farther the person is from a health centre but the effect is small. Having health insurance does help those whose travel cost is high to come to a health centre when the person is sick. A positive and significant coefficient for distance to the provincial capital and health insurance could mean that having health insurance encourages people far from the provincial capital to use a local health centre even though the services are not as good as those in the provincial capital.

(Table 4 is here)

Related to education, in general it can be seen that having health insurance encourages health service usage more, the higher the level of education one has when sick. On household income, it can be seen from Table 4 that having health insurance encourages health service usage more among people on a lower income. Hence, it can be seen that health insurance does relax one's budget constraints.

\subsection{Kind of Illness}

To understand the kind of illness that encourage utilisation of health services when one has a health insurance, this paper estimates model (1a) for those reporting feel a similar illness. The results can be seen in Table 5. It can be seen that the highest impact of having health insurance on health service utilisation happens when one feels of having an asthma attack or breathing difficulty, while the lowest impact is in the case of diarrhea. This is understandable since Indonesians tend to treat asthma attack or breathing difficulty as a more serious illness than diarrhea.

(Table 5 is here)

\section{Conclusion}


Indonesia has gone through a long history of health insurance provision, with expansion in terms of types and coverage. There has been the development of other types of health insurance in addition to those which are intended to cover a particular group of employees or employers (for example Jamsostek). Since 2004 with the construction of Askeskin, there have been types of health insurance intended for the poor, as one of the social assistance programs in Indonesia.

A decade later, since early 2014, the Government of Indonesia further aims to ensure that every Indonesian will be covered by health insurance by 2019. A new scheme called 'Universal National Health Insurance' was launched. The first stage of the target is to insure more than 120 million people in 2014 . The proportion of the population holding health insurance which has been increasing over time, will be expected to continue to rise with this new scheme.

Nevertheless, it remains debatable whether either the various health insurance/care schemes available now or the new single universal type of health insurance mean that holders of health insurance are more willing to seek medical treatment compared to those without. This is the main objective of this paper. This paper also investigates who are affected the most; i.e. more willing to use health services when sick, by the availability of health insurance. As the Universal National Health Insurance has just been launched in 2014, we are not able to examine its impact in this paper. The 2007 Susenas data merged with the 2007 Riskesdas are the main source dataset for this paper.

The main result of this paper is that having health insurance would increase the probability of utilising health services utilisation by approximately 8 percentage points when people feel sick or by approximately 5 percentage points if included those who do not feel sick. A loose interpretation of this result is the following. in 2007, approximately 26.5 percent of the population own health insurance. Providing the other 73.5 percent of the population with health insurance means an additional of approximately 4 percent of the population utilizing health services; i.e. the number of outpatient people (in the last one month) will increase from 
approximately 14 percent of the population to approximately 20 percent of the population, or the number of outpatient people (in the last one month) will increase by approximately 29 percent.

Among the different schemes available, private health insurance, health cost reimbursement by company and Jamsostek are estimated to have a lower impact on increasing the utilisation of health services than other health insurance schemes. Less likely that poorer people own these three types of health insurance. If they have, poorer people are mostly among members of the other health insurances which impacts are higher. This result indicates that the poor benefit more from the provision of health insurance. This result is also confirmed by the fact that the lower the household income is, proxied by household food expenditure, the greater the impact of having health insurance is on health service utilisation.

Having health insurance does encourage those who live far away to utilise health services and those whose health facilities in their area are rather limited (not as good as the ones in the provincial capital). Although there is some budget constraints remain, having health insurance does help to relax household budget constraints so people seek professional health treatment when a member of the household is sick. Hence, if the goal of providing health insurance is to encourage sick people to seek professional medical treatment, to perform as an enabling factor as discussed in the literature section, this goal in general has been achieved.

The question remaining is whether increasing the probability of utilising health services by 5 to 8 percentage point is good enough, considering that the cost of providing health insurance, particularly subsidised insurance, is rather large for the government. This question is not within the scope of this paper, and further studies are needed to deal with this question. This paper however indicates the importance of other factors in encouraging the utilisation of health services.

Having more health centres, particularly in remote areas, and better quality of health services are among the policy implications of this paper. Hence, it is clear that to 
encourage higher utilisation of health services to induce a better health status of the population, not only programs to relax household budget constraints are needed, but also programs to improve the supply side of health services.

Indonesia's previous experience has shown that the health care system has been relatively well-developed to face challenges in the increase in demand of utilisation of health services (such as in the case of the financial crisis in 1998). Nevertheless, stronger commitment not only from the central government, but also from the local government is required to respond to potentially more challenges in providing health services for everyone.

These may include providing incentives to further encourage the private sector to provide more health services, particularly in remote areas. Balancing priorities among those programs is the challenges faced by the Indonesian government. Incremental steps with strong monitoring and evaluation processes and continued improvement of programs to encourage higher utilisation of health services might be the strategy that the Indonesian government should adopt. 


\section{References}

Aji, B., De Allegri, M., Souares, A., \& Sauerborn, R. (2013). The Impact of Health Insurance Programs on Out-of-Pocket Expenditures in Indonesia: An Increase or a Decrease?. International journal of environmental research and public health, 10(7), 2995-3013.

Andersen, R. M., \& Davidson, P. L. (2007). Improving access to care in America. Changing the US health care system: key issues in health services policy and management. 3a. edición. San Francisco: Jossey-Bass, 3-31.

Babitsch, B., Gohl, D., \& von Lengerke, T. (2012). Re-revisiting Andersen's Behavioral Model of Health Services Use: a systematic review of studies from 1998-2011. GMS Psycho-Social-Medicine, 9.

Brodsky, J., Habib, J., \& Hirschfeld, M. (Eds.). (2003). Long-term care in developing countries: ten case-studies. World Health Organization.

Ekman B. (2004). Community-based health insurance in low-income countries: A systematic review of the evidence. Health Policy and Planning 19, 249-70.

Ekman, B., Liem, N. T., Duc, H. A., \& Axelson, H. (2008). Health insurance reform in Vietnam: a review of recent developments and future challenges. Health policy and planning, 23(4), 252-263.

Ensor, T., \& Cooper, S. (2004). Overcoming barriers to health service access: influencing the demand side. Health policy and planning, 19(2), 69-79.

Erlyana, E., Damrongplasit, K.K \& Melnick, G. (2011). Expanding health insurance to increase health care utilisation: Will it have different effects in rural vs urban areas? Health Policy, 100, 273-281.

Harimurti, P., E. Pambudi, A. Pigazzini, A. Tandon (2013). The nuts and bolts of Jamkesmas - Indonesia's government-financed health coverage program for the poor and near-poor. Universal Health Coverage (UNICO) studies series; no. 8. Washington D.C. : The Worldbank. Available from: http://documents.worldbank.org/curated/en/2013/01/17480791/nuts-boltsjamkesmas-indonesias-government-financed-health-coverage-program-poornear-poor

Heckman, J. J. (1979). Sample selection bias as a specification error. Econometrica, 47(1),153-161. 
Hidayat, B., \& Pokhrel, S. (2009). The selection of an appropriate count data model for modelling health insurance and health care demand: case of Indonesia. International journal of environmental research and public health, 7(1), 9-27 Hidayat, B., Thabrany, H., Dong, H., \& Sauerborn, R. (2004). The effects of mandatory health insurance on equity in access to outpatient care in Indonesia. Health Policy and Planning, 19(5), 322-335

Hotchkiss, D. R., \& Jacobalis, S. (1999). Indonesian heath care and the economic crisis: is managed care the needed reform? Health Policy, 46(3), 195-216. Howes, S., \& Davies, R. (2014). Survey of Recent Developments. Bulletin of Indonesian Economic Studies, 50(2), 157-183.

Johar, M. (2009). The impact of the Indonesian health card program: A matching estimator approach. Journal of health economics, 28(1), 35-53.

Johar, M. (2010). The effect of a public health card program on the supply of health care. Social Science \& Medicine, 70(10), 1527-1535.

Jütting, J. P. (2003). Do community-based health insurance schemes improve poor people's access to health care? Evidence from rural Senegal. World Development, 32(2), 273-288

Kristiansen, S., \& Santoso, P. (2006). Surviving decentralisation?: Impacts of regional autonomy on health service provision in Indonesia. Health Policy, 77(3), 247259.

Lagomarsino, G., Garabrant, A., Adyas, A., Muga, R., \& Otoo, N. (2012). Moving towards universal health coverage: health insurance reforms in nine developing countries in Africa and Asia. The Lancet, 380(9845), 933-943.

López-Cevallos, D. F., \& Chi, C. (2010). Health care utilisation in Ecuador: a multilevel analysis of socio-economic determinants and inequality issues. Health Policy and Planning, 25(3), 209-218.

Makinen, M., H. Waters, M. Rauch, N. Almagambetova, R. Bitran, L. Gilson, D. McIntyre, S. Pannarunothai, A.L. Pieto, G. Ubilla and S. Ram (2000). Inequalities in health care use and expenditures: empirical data from eight developing countries and countries in transition. Bulletin of the World Health Organization, 79(1), 55-65. 
McIntyre D. (2007). Learning from experience: health care financing in low- and middle-income countries. Geneva: Global Forum for Health Research

Miranti, R., Vidyattama, Y., Hansnata, E., Cassells, R., Duncan, A. (2013),'Trends in Poverty and Inequality in Decentralising Indonesia', the OECD Social, Employment and Migration Working Paper, No. 148, OECD Publishing Nugroho, G., \& Elliott, K. (1977), The Dana Sehat Programme in Solo, Indonesia. Proceedings of the Royal Society of London. Series B. Biological Sciences, 199(1134), 145-150.

OECD/WHO (2012), Health at a Glance: Asia/Pacific 2012, OECD Publishing. doi: $10.1787 / 9789264183902-e n$

Pakasi, T. A., Karyadi, E., Wibowo, Y., Simanjuntak, Y., Suratih, N. M. D., Salean, M., Darmawidjaja, N., van der Meer, J. W. M., van der Velden, K. \& Dolmans, W. M. V. (2009). Vitamin A deficiency and other factors associated with severe tuberculosis in Timor and Rote Islands, East Nusa Tenggara Province, Indonesia. European journal of clinical nutrition, 63(9), 1130-1135

Perrot, J., de Roodenbeke, E., Musango, L. \& Fritsche, G. (2010). Performance Incentives for Health Care Providers, Discussion Paper, No. 1 - 2010, WHO, Geneva

Pradhan, M., Saadah, F., \& Sparrow, R. (2007). Did the health card program ensure access to medical care for the poor during Indonesia's economic crisis?. The World Bank Economic Review, 21(1), 125-150.

Preker, A. S., \& Carrin, G. (Eds.). (2004). Health financing for poor people: resource mobilization and risk sharing. World Bank Publications

Rokx, C. (2009). Health financing in Indonesia: a reform road map. World Bank Publications.

Sanjaya, M. R. (2007). Health cost in Indonesia: evidences from IFLS and Susenas data. Munich Personal RePEc Archieve (MPRA) paper.

Scheil-Adlung, X. (2004). Sharpening the Focus on the Poor: Policy Options for Advancing Social Health Protection in Indonesia. ESS Paper, 19. ILO, Geneva. Simmonds, A. \& Hort, K. (2013). Institutional analysis of Indonesia's proposed road map to universal health coverage. Health Policy and Health Finance Knowledge 
Hub Working Paper Series, 33, The Nassal Institute for Global Health, University of Melbourne.

Soenarto, Y., Aman, A. T., Bakri, A., Waluya, H., Firmansyah, A., Kadim, M., Martiza, I., Prasetyo, D., Mulyani, N. S., Widowati, T., Soetjiningsih, Karyana, I.P.G., Sukardi, W., Bresee, J. \& Widdowson, M. A. (2009). Burden of severe rotavirus diarrhea in Indonesia. Journal of Infectious Diseases, 200(Supplement 1), S188S194

Soors, W., Devadasan, N., Durairaj, V., \& Criel, B. (2010). Community health insurance and universal coverage: multiple paths, many rivers to cross. World Health Report.

Sparrow, R. (2011) 'Social Health Insurance: Towards Universal Coverage for the Poor', in Employment, Living Standards and Poverty in Contemporary Indonesia, C. Manning and S. Sumarto (eds.), Singapore: Institute of Southeast Asian Studies.

Sparrow, R., Suryahadi, A., \& Widyanti, W. (2012). Social Health Insurance for the Poor: Targeting and Impact of Indonesia's Askeskin Programme. Social Science \& Medicine, 264-271.

Soedjono, I. (1956) Dana Sakit dan Djaminan Sosial untuk Buruh (Health Insurance and Social Security for Workers). Bandung: Masa Baru.

Suryahadi, A., Suharso, Y., \& Sumarto, S. (2001). Coverage and Targetting in the Indonesian Social Safety Net Programmes. ASEAN Economic Bulletin, 18(2).

Thabrany, H., G. Ascobat, Pujianto, L. Mayanda, Mahlil, B.S. Budi (2003), "Social health insurance in Indonesia: current status and the proposed national health insurance." Paper presented at Social Health Insurance Workshop by WHO SEARO; 13-15 March.

Vidyattama, Y. (2013) Regional convergence and the role of neighborhood effect in decentralized Indonesia, Bulletin of Indonesian Economic Studies, 49(2), 193211

Wagstaff, A. \& Pradhan, M., (2005). Health insurance impacts on health and nonmedical consumption in a developing country. World Bank Policy Research Working Paper 3563 
Wagstaff, A. (2007). Health insurance for the poor: initial impacts of Vietnam's health care fund for the poor. World bank policy research working paper, (4134).

Wagstaff, A., Lindelow, M., Jun, G., Ling, X., \& Juncheng, Q. (2009). Extending health insurance to the rural population: An impact evaluation of China's new cooperative medical scheme. Journal of health economics, 28(1), 1-19.

Wagstaff, A. (2014). We just learned a whole lot more about achieving Universal Health Coverage. (http://blogs.worldbank.org/developmenttalk/we-justlearned-whole-lot-more-about-achieving-universal-health-coverage) , downloaded on 20 October 2014

World Bank, (2011). Indonesia health sector review February 2011 (Jakarta).

World Bank (2012). Indonesia health sector review June 201s (Jakarta).

(http://www.worldbank.org/content/dam/Worldbank/document/EAP/Indonesia/HS R-Overview-.pdf)

World Bank, (2013). World Development Indicators 2013. World Bank Publications. 
Table 1. Milestones of Health Insurance Provision in Indonesia

\begin{tabular}{|c|c|c|c|}
\hline Year & Name of the Program & Target Beneficiaries & Management/Organiser \\
\hline 1968 & Askes & $\begin{array}{l}\text { Both active and retired civil } \\
\text { servants and direct family } \\
\text { members (Mandatory) }\end{array}$ & $\begin{array}{l}\text { Ministry of Health, together with Askes } \\
\text { Persero }\end{array}$ \\
\hline 1969-1990s & $\begin{array}{l}\text { Community-based health } \\
\text { insurance }(\mathrm{CBHI}) \text { - Health Funds } \\
\text { and its promotion of Dana Sehat }\end{array}$ & $\begin{array}{l}\text { Members of communities, } \\
\text { informal sector (Voluntary) }\end{array}$ & $\begin{array}{l}\text { Cooperation, community organisation } \\
\text { with leaders of communities responsible } \\
\text { for establishing a structure for health } \\
\text { activities and for carrying out decisions } \\
\text { made by their community. }\end{array}$ \\
\hline 1992 & $\begin{array}{l}\text { Workforce Social Security - } \\
\text { Jamsostek (Jaminan Social } \\
\text { Tenaga Kerja) }\end{array}$ & $\begin{array}{l}\text { Private formal sector employees } \\
\text { and their dependents } \\
\text { (Mandatory) }\end{array}$ & $\begin{array}{l}\text { Ministry of Manpower and } \\
\text { Transmigration with PT Jaminan Sosial } \\
\text { Tenaga } \\
\text { Kerja (PT Jamsostek Persero) }\end{array}$ \\
\hline 1992 & $\begin{array}{l}\text { Community Health Insurance } \\
\text { Scheme- JPKM/HMOs (Jaminan } \\
\text { Pemeliharaan Kesehatan } \\
\text { Masyarakat) - }\end{array}$ & $\begin{array}{l}\text { Informal sector, civil servants and } \\
\text { military for their uncovered } \\
\text { dependents (Voluntary) }\end{array}$ & $\begin{array}{l}\text { BAPELs (managed care organisations) for } \\
\text { daily application of JPKM and } \\
\text { Government and local professional } \\
\text { organisations. (BADAN PEMBINA) which } \\
\text { monitor the implementation of the JPKM. } \\
\text { The strategic unit for JPKM is the district. }\end{array}$ \\
\hline 1994 & $\begin{array}{l}\text { The Health Card (Kartu Sehat) } \\
\text { was launched to reduce } \\
\text { asymmetry in access to health } \\
\text { care }\end{array}$ & Targeted poor households & Ministry of Health \\
\hline 1998 & $\begin{array}{l}\text { Social Safety Net - JPS (Jaring } \\
\text { Pengaman Sosial) } \\
\text { The program was not limited to } \\
\text { health subsidies but also to } \\
\text { cover workfare, subsidised rice } \\
\text { sales, targeted scholarships, and } \\
\text { village block grants. The } \\
\text { program was implemented using } \\
\text { the JPKM-HMO model as the } \\
\text { 'carriers' at the provincial } \\
\text { /district level. }\end{array}$ & $\begin{array}{l}\text { This was the second large scale } \\
\text { health card program which were } \\
\text { issued to the targeted poor } \\
\text { households }\end{array}$ & $\begin{array}{l}\text { Ministry of Health took over the program } \\
\text { in } 1999 \text { as the organiser since most JKPMs } \\
\text { established to support the SSN have } \\
\text { failed to perform. }\end{array}$ \\
\hline 2001 & \multicolumn{3}{|c|}{ Decentralisation law was implemented } \\
\hline 2004 & $\begin{array}{l}\text { Health Insurance for the Poor- } \\
\text { Askeskin/ (Asuransi Kesehatan } \\
\text { Masyarakat Miskin) }\end{array}$ & $\begin{array}{l}\text { Identified poor, based on } \\
\text { individual and household } \\
\text { targeting }\end{array}$ & Up to 2007 managed by PT Askes \\
\hline 2004 & \multicolumn{3}{|c|}{ The Law for National Social Security System (40/2004) was issued } \\
\hline 2008 & $\begin{array}{l}\text { Health Insurance Scheme for the } \\
\text { Population - Jamkesmas/ } \\
\text { Jaminan Kesehatan Masyarakat } \\
\text { replaced Askeskin }\end{array}$ & $\begin{array}{l}\text { Extend the coverage to include } \\
\text { the near poor, larger target } \\
\text { population than the Askeskin }\end{array}$ & $\begin{array}{l}\text { Ministry of Health took over full } \\
\text { management of the program with PT } \\
\text { Askes still responsible for managing the } \\
\text { membership }\end{array}$ \\
\hline 2010 & \multicolumn{3}{|c|}{$\begin{array}{l}\text { Passing of Law No. 17: The National Development Middle Plan (RPJMN) reconfirmed Indonesia's commitment to } \\
\text { provide universal health coverage by } 2014\end{array}$} \\
\hline 2011 & \multicolumn{3}{|c|}{$\begin{array}{l}\text { The Legislation on the Social Security Management Agency (Badan Penyelenggara Jaminan Sosial (BPJS) (Law No } \\
\text { 24/2011) was passed, which mandated that the Social Security Agency (BJPS) would be operational by January } 1 \text {, } \\
2014\end{array}$} \\
\hline 2014 & $\begin{array}{l}\text { The launch of Universal Health } \\
\text { Insurance }\end{array}$ & Aims to cover everyone by 2019 & BPJS \\
\hline
\end{tabular}

Source: Brodsky et al. (2003, p. 146); Johar (2009, 2010); Rokx et al. (2009, Table 3.1, p.30 ); Scheil-Adlung (2004);

Sparrow(2011); Suryahadi et al. (2001); Soors et al (2010). 
Table 2. Percentage of Outpatients and Health Insurance Ownership in 2007.

\begin{tabular}{|c|c|c|c|}
\hline$(1)$ & $\begin{array}{c}\text { Outpatient } \\
(2) \\
\end{array}$ & $\begin{array}{c}\text { Own } \\
\text { health } \\
\text { insurance } \\
(3) \\
\end{array}$ & $\begin{array}{c}\text { Outpatient } \\
\text { with } \\
\text { health } \\
\text { insurance } \\
\text { (4) } \\
\end{array}$ \\
\hline & \multicolumn{3}{|c|}{$(\%)$} \\
\hline All person & 14.2 & 26.5 & 4.7 \\
\hline - Sumatera & 13.3 & 26.2 & 4.5 \\
\hline - Java-Bali & 14.5 & 24.9 & 4.4 \\
\hline - Nusa Tenggara & 20.2 & 42.5 & 9.7 \\
\hline - Kalimantan & 12.1 & 28.3 & 4.6 \\
\hline - Sulawesi & 12.9 & 29.6 & 4.9 \\
\hline - Maluku Papua & 13.0 & 39.5 & 6.0 \\
\hline Not ill & n.a. & 24.9 & n.a. \\
\hline Any illness & 44.8 & 27.7 & 13.7 \\
\hline - Sumatera & 42.7 & 29.5 & 14.3 \\
\hline - Java-Bali & 46.8 & 28.3 & 14.4 \\
\hline - Nusa Tenggara & 48.0 & 45.9 & 23.1 \\
\hline - Kalimantan & 37.9 & 31.7 & 14.5 \\
\hline - Sulawesi & 37.5 & 33.7 & 14.2 \\
\hline - Maluku Papua & 39.0 & 39.8 & 17.9 \\
\hline Fever & 46.4 & 27.4 & 13.6 \\
\hline Cough & 29.3 & 29.8 & 9.8 \\
\hline Flu/cold & 18.7 & 29.1 & 6.5 \\
\hline Asthma & 56.0 & 31.8 & 20.0 \\
\hline Diarrhoea & 51.3 & 28.0 & 15.1 \\
\hline Headache & 28.1 & 28.7 & 9.6 \\
\hline Toothache & 32.6 & 28.8 & 11.4 \\
\hline Other unspecified illness & 50.8 & 31.6 & 17.2 \\
\hline
\end{tabular}

Source: Authors' calculation based on Susenas (2007)

Note: The percentage in columns (2), (3) or (4) is calculated as a proportion of the set of population indicated in column (1). Notation n.a. means not available 
Table 3. Marginal Effect on Health Utilisation

\begin{tabular}{|c|c|c|c|c|c|c|}
\hline & \multicolumn{2}{|c|}{$\begin{array}{c}\text { Probit estimation } \\
\text { of those who are } \\
\text { sick }\end{array}$} & \multicolumn{2}{|c|}{ Heckman Selection } & \multicolumn{2}{|c|}{ Probit estimation } \\
\hline & $\begin{array}{l}\mathrm{dy} / \mathrm{dx} \\
(1 \mathrm{a}) \\
\end{array}$ & $\begin{array}{l}\mathrm{dy} / \mathrm{dx} \\
(1 \mathrm{~b}) \\
\end{array}$ & $\begin{array}{c}\mathrm{dy} / \mathrm{dx} \\
(1 \mathrm{c})\end{array}$ & $\begin{array}{l}\mathrm{dy} / \mathrm{dx} \\
(1 \mathrm{~d}) \\
\end{array}$ & $\begin{array}{c}\text { dy/dx } \\
(3 a)\end{array}$ & $\begin{array}{l}\mathrm{dy} / \mathrm{dx} \\
(3 \mathrm{~b})\end{array}$ \\
\hline Ownership of any health insurance & $0.075^{* * *}$ & & $0.056^{* * *}$ & & $0.048^{* * *}$ & \\
\hline $\begin{array}{l}\text { - Health insurance for civil } \\
\text { servant (Askes)/ veteran/ retiree }\end{array}$ & & $0.099^{* * *}$ & & $0.074^{* * *}$ & & $0.031^{* * *}$ \\
\hline $\begin{array}{l}\text { - Financial Aid/ reimbursement } \\
\text { by company }\end{array}$ & & $0.062^{* * *}$ & & $0.046^{* * *}$ & & $0.026^{* * *}$ \\
\hline $\begin{array}{l}\text { - Health care for the poor } \\
\text { (JPKMM/Health Card/JPK } \\
\text { Gakin/Askeskin) }\end{array}$ & & $0.065^{* * *}$ & & $0.049^{* * *}$ & & $0.053^{* * *}$ \\
\hline $\begin{array}{l}\text { - Social insurance for worker } \\
\text { (Jamsostek ) }\end{array}$ & & $0.066^{* * *}$ & & $0.05^{* * *}$ & & $0.031^{* * *}$ \\
\hline - Private health insurance & & $0.04^{* * *}$ & & $0.031^{* * *}$ & & $0.023^{* * *}$ \\
\hline - $\quad$ Health fund & & $0.102^{* * *}$ & & $0.077^{* * *}$ & & $0.066^{* * *}$ \\
\hline $\begin{array}{l}\text { - JPKM and other regional health } \\
\text { insurance schemes }\end{array}$ & & $0.081^{* * *}$ & & $0.06^{* * *}$ & & $0.049^{* * *}$ \\
\hline $\begin{array}{l}\text { Time needed to nearest health } \\
\text { service provider (day) }\end{array}$ & $-0.013^{* * *}$ & $-0.013^{* * *}$ & $-0.010^{* * *}$ & $-0.010^{* * *}$ & $-0.005^{* * *}$ & $-0.005^{* * *}$ \\
\hline $\begin{array}{l}\text { Distance to the provincial capital } \\
\text { city }(100 \mathrm{~km})\end{array}$ & $-0.015^{* * *}$ & $-0.015^{* * *}$ & $-0.011^{* * *}$ & $-0.012^{* * *}$ & $-0.004^{* * *}$ & $-0.004^{* * *}$ \\
\hline \multicolumn{7}{|l|}{ Region (base:Java-Bali) } \\
\hline Sumatera & $-0.049^{* * *}$ & $-0.048^{* * *}$ & $-0.036^{* * *}$ & $-0.036^{* * *}$ & $-0.004^{* * *}$ & $-0.004^{* * *}$ \\
\hline Kalimantan & $-0.115^{* * *}$ & $-0.114^{* * *}$ & $-0.084^{* * *}$ & $-0.086^{* * *}$ & $-0.03^{* * *}$ & $-0.029^{* * *}$ \\
\hline Sulawesi & $-0.100^{* * *}$ & $-0.100^{* * *}$ & $-0.073^{* * *}$ & $-0.074^{* * *}$ & $-0.007^{* * *}$ & $-0.007^{* * *}$ \\
\hline Maluku-Papua & $-0.076^{* * *}$ & $-0.076^{* * *}$ & $-0.055^{* * *}$ & $-0.056^{* * *}$ & $-0.010^{* * *}$ & $-0.01^{* * *}$ \\
\hline NusaTenggara & $0.017^{* * *}$ & $0.017^{* * *}$ & $0.014^{* * *}$ & $0.014^{* * *}$ & $0.056^{* * *}$ & $0.054^{* * *}$ \\
\hline Log likelihood & -186042 & -186030 & -724806 & -724794 & -331223 & -331133 \\
\hline Observations & 277921 & 277921 & 848585 & 848585 & 848585 & 848585 \\
\hline
\end{tabular}


Table 4. Partial Marginal Effect of Variables Interacting with Health Insurance

Ownership

\begin{tabular}{|c|c|c|c|c|c|c|}
\hline \multirow[t]{2}{*}{$\begin{array}{l}\text { Interacting variable with } \\
\text { health care/insurance } \\
\text { ownership }\end{array}$} & \multicolumn{2}{|c|}{$\begin{array}{c}\text { Probit estimation } \\
\text { of those who are } \\
\text { sick }\end{array}$} & \multicolumn{2}{|c|}{ Heckman Selection } & \multicolumn{2}{|c|}{ Probit regression } \\
\hline & $(d y / d x)^{a}$ & $(\mathrm{dy} / \mathrm{dx})^{\mathrm{b}}$ & $(\mathrm{dy} / \mathrm{dx})^{\mathrm{a}}$ & $(\mathrm{dy} / \mathrm{dx})^{\mathrm{b}}$ & $(d y / d x)^{a}$ & $(\mathrm{dy} / \mathrm{dx})^{\mathrm{b}}$ \\
\hline $\begin{array}{l}\text { health care/insurance } \\
\text { ownership (constant) }\end{array}$ & $0.051^{* * *}$ & $0.023^{* *}$ & $0.037^{* * *}$ & $0.016^{*}$ & $0.037^{* * *}$ & $0.012^{* *}$ \\
\hline $\begin{array}{l}\text { Time needed to nearest } \\
\text { health service provider (day) }\end{array}$ & 0.001 & 0.002 & 0.001 & 0.001 & 0.001 & 0.001 \\
\hline $\begin{array}{l}\text { Distance to the provincial } \\
\text { capital city }(100 \mathrm{~km})\end{array}$ & $0.010^{* * *}$ & $0.011^{* * *}$ & $0.007^{* * *}$ & $0.008^{* * *}$ & $0.007^{* * *}$ & $0.006^{* * *}$ \\
\hline \multicolumn{7}{|l|}{ Region (base:Java-Bali) } \\
\hline Sumatera & $0.022^{* * *}$ & $0.029^{* * *}$ & $0.016^{* * *}$ & $0.02^{* * *}$ & $0.011^{* * *}$ & $0.014^{* * *}$ \\
\hline NusaTenggara & 0 & 0.003 & -0.001 & 0.002 & -0.001 & -0.001 \\
\hline Kalimantan & $0.066^{* * *}$ & $0.074^{* * *}$ & $0.047^{* * *}$ & $0.052^{* * *}$ & $0.027^{* * *}$ & $0.031^{* * *}$ \\
\hline Sulawesi & $0.017^{* * *}$ & $0.022^{* * *}$ & $0.013^{* * *}$ & $0.015^{* * *}$ & $0.011^{* * *}$ & $0.011^{* * *}$ \\
\hline Maluku-Papua & $0.024^{* *}$ & $0.033^{* * *}$ & $0.017^{* *}$ & $0.023^{* * *}$ & $-0.02^{* * *}$ & $-0.015^{* * *}$ \\
\hline Number of family member & & $0.005^{* * *}$ & & $0.003^{* * *}$ & & $0.004^{* * *}$ \\
\hline $\begin{array}{l}\text { Food Expenditure (million } \\
\mathrm{Rp} / \text { month) }\end{array}$ & & $-0.03^{* * *}$ & & $-0.021^{* * *}$ & & $-0.018^{* * *}$ \\
\hline Log likelihood & -185986 & -185912 & -724749 & -724675 & -331127 & -330938 \\
\hline Observations & 277921 & 277921 & 848585 & 848585 & 848585 & 848585 \\
\hline $\begin{array}{l}\text { ote: a equations include control } v \\
\text { Status, Sector of employm } \\
\text { expenditure as the proxy fo } \\
\text { b equations include both con } \\
\text { Household size, Education, } \\
\text { District Health Budget and } \\
{ }^{*},{ }^{* *}, \text { and }{ }^{* * *} \text { are } 10 \%, 5 \% \text {, ar }\end{array}$ & $\begin{array}{l}\text { riables for } \\
\text { t, GRP per c } \\
\text { income bu } \\
\text { ol variable } \\
\text { mploymen } \\
\text { ood expend } \\
1 \% \text { signifi }\end{array}$ & $\begin{array}{l}\text { ex, Age, Ho } \\
\text { apita, Distri } \\
\text { not the int } \\
\text { and intera } \\
\text { Status, Sec } \\
\text { ture as the } \\
\text { ance, respe }\end{array}$ & $\begin{array}{l}\text { sehold size, } \\
\text { t Health Bu } \\
\text { racting vari } \\
\text { ting variabl } \\
\text { pr of employ } \\
\text { roxy for inc } \\
\text { tively }\end{array}$ & $\begin{array}{l}\text { Education, } \\
\text { lget and Fo } \\
\text { bles } \\
\text { s for Sex, A } \\
\text { ment, GRP } \\
\text { ome }\end{array}$ & $\begin{array}{l}\text { e, } \\
\text { er capita, }\end{array}$ & \\
\hline
\end{tabular}


Table 5. Marginal Effect on Health Utilisation for Each Case of Illness

\begin{tabular}{lccc}
\hline \multicolumn{1}{c}{$\mathrm{dy} / \mathrm{dx}$} & $\begin{array}{c}\text { Ownership of any } \\
\text { health insurance }\end{array}$ & Observations & $\begin{array}{c}\text { Log } \\
\text { likelihood }\end{array}$ \\
\hline Fever & $0.067^{* * *}$ & 14670 & -9675 \\
Cough & $0.058^{* * *}$ & 11268 & -6510 \\
Flu/cold & $0.054^{* * *}$ & 12661 & -5846 \\
Asthma/ Breath difficult & $0.110^{* * *}$ & 4176 & -2800 \\
Diarrhea & $0.051^{* * *}$ & 5061 & -3380 \\
Headache & $0.082^{* * *}$ & 14111 & -7980 \\
Toothache & $0.097^{* * *}$ & 5530 & -3184 \\
Others unspecified & $0.055^{* * *}$ & 56241 & -38284 \\
illness & & 50418 \\
\hline
\end{tabular}

Note: All the equations include control variable for Sex, Age, Household size, Education, Employment Status, Sector of employment, GRP per capita, District Health Budget and Food expenditure as the proxy for income ${ }^{*},{ }^{* *}$, and ${ }^{* * *}$ are $10 \%, 5 \%$, and $1 \%$ significance, respectively 